Further investigations along these lines are at present being made and will form the basis of a subsequent communication.

$$
\text { A. T. WrILIS }
$$

G. Hoввs

Sehool of Medicine,

University of Leeds, Leeds 2.

March 25.

1 Hayward, Nancy J., Brit. Med. J., i, 811, 916 (1941).

2 Hayward, Nancy J., J. Path. Bact., 65, 285 (1943).

${ }^{3}$ Bray, J., ant King, E. J., J. Puth. Bact., 54, 287 (1442). Reed, 4 . B., Dubos's "Bacterial and Mycotic Infections of Mnu",
lit eil., 357 (Lippincott, Philadelphia, 1948).

\section{Proteolysis of Collagen}

TT was shown by Linderstrøm-Lang and co-workers ${ }^{1}$ that the tryptic hydrolysis of $\beta$-lactoglobulin involves the reversible denaturation of the protein as a prelim. inary stage. A consideration of known facts, together with new evidence obtained in connexion with an investigation of the mechanism of bating of skins in leather manufacture ${ }^{2}$, indicates that collagen and procollagen are also denatured by the enzyme prior to hydrolysis. Bating is a process in which skins, after liming and deliming, are treated with a proteolytic enzyme (usually trypsin) in order to produce a soft leather. The process has been shown to involve the removal of degraded collagen (a form of collagen in which the fibrillar structure has disintegrated and which has been named 'progelatin'2) produced by the swelling action of lime, and is normally carried out at about $37^{\circ} \mathrm{C}$. 'Temperature control is eritical since little or no action takes place below $35^{\circ} \mathrm{C}$., and above $40^{\circ} \mathrm{C}$. rapid digestion of intact collagen occurs, leading to a loss of leather-making substance. The lower limit is explained by the fact that progelatin must be converted into gelatin before it can be hydrolysed by the enzyme. If, however, the skin is heated to $40-45^{\circ} \mathrm{C}$. before adding the enzyme, bating can be carried out at a much lower temperature, for example, at $27^{\circ} \mathrm{C}$. in about twice the time required at $37^{\circ} \mathrm{C}$, which is in accord with the temperature coefficient of proteolytic enzymes acting on gelatin ${ }^{3}$. The higher temperature required to heat the progelatin in the absence of enzyme than in its presence is indicative of a denaturation stage which can be catalysed by the enzyme. As denaturation is believed to involve rupture of hydrogen bonds between parallel molecular chains, the enzyme functions as a hydrogen bond breaker in a similar manner to chemicals such as alkali, urea, potassium thiocyanate, etc.

Hydrogen bond breaking by chemicals can be followed by the decrease in hydrothermal shrinkage temperature $\left(T_{s}\right)$, but fails with proteolytic enzymes since denaturation is immediately followed by hydrolysis, so that shrinkage does not occur. It is impossible to wash out completely or inactivate the enzyme adsorbed on the collagen, which is remarkably stable so that even plunging the enzyme-treated collagen into boiling water results in appreciable hydrolysis before the enzyme is inactivated 4 . Any chemical treatment that lowers the $T_{s}$ of collagen results in an increased rate of attack by trypsin at $37-40^{\circ} \mathrm{C}$. because the activation energy for enzyme denaturation is reduced. Various native fish collagens are attacked by trypsin at temperatures related to their hydrothermal shrinkage temperatures ${ }^{5}$. Fish collageiss are believed to differ from mammalian collagen principally in the degree of hydrogen bonding ${ }^{6}$ and so behave similarly to chemically treated mammalian collagen.

G. H. Green

British Leather Manufacturers' Research Association, Milton Park,

Egham, Surrey. March 22.

' Linderstrom-Lang, K., Hotchkiss, R. D., and Johansen, G., Nature, 142, 996 (1938). Christensen, L. K., ibid., 168, 1003 (1949). 117 (1950).

${ }^{2}$ Green, G. H., J. Soc. Leath. Trades Chem. (in the press).

${ }^{3}$ Green, G. H., J. Soc. Leath. Trades Chem., 40, 369 (1956).

- Neuman. R. E., and Tytell, A. A., Proc. Soc. Hxp. Biol. N.Y., 73. 409 (1950). Deasy, C., J. Amer. Leath. Chem. Assoc., 50, 463 (1955). Green, G. H. (unpublished work).

5 Takahashi, T., and Takel, M., Bull. Jap. Soc. Sci. Fish., 20, 421 (1954).

Gustavson, K. H., Nature, 175, 70 (1955); Svensk. Kem. Tiidskr., 67, $116(1955) ;$ J. Amer. Leath. Chem. Assoc., 50, 239 (1955).

\section{Size and Shape of Cartilage Mucoprotein}

'I'HE chondroitin sulphate-protein complex of cartilage was extracted from fresh homogenized bovine nasal septa by 30 per cent potassium chloride and precipitated with absolute alcohol after dialysis against running tap water and addition of potassium acetate; all operations were carried out at $2^{\circ} \mathrm{C}$. The final product was analogous in chemical composition to the mucoprotein of Shatton and Schubert'. Solutions of the mucoprotein in phosphate buffer $M / 15, p H \quad 7 \cdot 0$, were studied by viscometry, sedimentation, light scattering and flow birefringence.

The viscosimetric measurements were carried out at a velocity gradient $G=0.246 \mathrm{sec}^{-1}$ in a Couette apparatus; the intrinsic viscosity at $25^{\circ} \mathrm{C}$. was $[\eta]=207$ c.G.S. units. The sedimentation coefficient at innmite diıution and $2 v^{\circ} \mathrm{C}$. was $s_{0}=6.85 \times 10^{-13}$ c.G.s. units; the considerable spreading of the sedimenting buundary suggested a wide polydispersity of the mucoprotein. Determinations of lightscattering at $\lambda=5460 \mathrm{~A}$. (the specific refractive index increment was $\mathrm{d} n / \mathrm{d} c=0 \cdot 1680$ per gm./ml.) gave the following results : $M_{w}=1.98 \times 10^{6} ; I_{45} / I_{138}=$ $2 \cdot 18 ; R_{z}=1180 \mathrm{~A}$. ( $R_{z}$ being the $Z$-average radius of gyration); the anisotropy was negligible.

I have carried out the double extrapolation (to) zero angle and zero concentration) of the Zimm plot obtained in the diagram $P^{-1}(\theta)$ vs. $\mu^{2} R^{2}(\mu=$ $\frac{4 \pi}{\lambda^{\prime}} \sin \frac{\theta}{2}, \lambda^{\prime}$ being the wave-length of light in the solution, $\theta$ the angle between the incident and scattered beams) in order to compare the plot with the curves pertaining to spheres, coils and rods, respectively; it is $\mathrm{known}^{2}$ that the curves relating to polydisperse systems fall below those of monodisperse systems (the latter are shown in Fig. 1).

As is evident from Fig. 1, the sphere model seems to be quite improbable; furthermore, it would require a hydrated specific volume (as deduced from $R_{z}$ ) of $V^{\prime}=4,450 \mathrm{ml}$./gm., which appears to be much too high. A polydisperse system of rods, such as was suggested by Mathews and Lozaityte ${ }^{3}$, though not incompatible with the light-scattering results, seems also highly improbable. The length of the rods (as deduced from $R_{z}$ ) would be about $4000 \mathrm{~A}$.; such a system could scarcely fail to exhibit a strong flow birefringence, like, for example, tobacco mosaic virus 